\title{
Online Gambling under EU Law: Strolling Between Controlled Expansion and Genuine Diminution of Gambling Opportunities
}

\begin{abstract}
JANJA HOJNIK
Abstract This article outlines some of the ambiguities arising from the endeavours of the EU Court to offer the national courts sufficiently clear interpretation of EU rules on free movement of services in respect of various national restrictions of online gambling that would enable them to make rulings in increasingly high numbers of cases in which foreign providers are restricted from accessing markets of EU Member States. It is submitted that this casuistic approach by the Court should not be considered as satisfying and that harmonising instruments should be adopted by the EU legislators, instead. Yet however, this is less realistic than ever before, as the Commission in situation of a total lack of the Member States « consensus stepped away from its efforts to pave the way to at least minimum standards of gambling offerings and provision of customers « protection, leaving it further to the EU and national courts to balance between controlled expansion and genuine diminution of gambling opportunities so as to weigh between free movement of services and opposing legitimate aims of the Member States.
\end{abstract}

Keywords: - digital market - online betting - free movement of services $\bullet$ public interest $\bullet$ justifying restrictions on foreign provision of gambling •

CorRespondence AdDress: Janja Hojnik, PhD, Full Professor, University of Maribor, Faculty of Law, Mladinska ulica 9, 2000 Maribor, Slovenia, e-mail: janja.hojnik@um.si. 
»At one moment I must have had in my hands gathered there within a space of five minutes - about 4000 gulden. That, of course, was the proper moment for me to have departed, but there arose in me a strange sensation as of a challenge to Fate - as of a wish to deal her a blow on the cheek, and to put out my tongue at her. Accordingly, I set down the largest stake allowed by the rules - namely, 4000 gulden - and lost. Fired by this mishap, I pulled out all the money left to me, staked it all on the same venture, and-again lost! Then I rose from the table, feeling as though I were stupefied. What had happened to me I did not know."

F. M. Dostoyevsky, Gambler, chapter IV, 1866

Introduction

Why people gamble is one of the great unanswered questions. We all know very well that, in the long term, the gamblers « financial outcome from gambling will always be negative. There is more to gambling than mere pursuit of money and there are far too few aberrant and abusive gamblers who are overwhelmed by their losses to explain gambling as a social phenomenon. If games of chance did not satisfy some of the deepest, basic or even »original« human needs, people would not bet.

Gambling is also among the hottest potatoes in terms of its regulation at the EU level. This is the case because regulations unfortunately are strongly influenced by both economic and political interests, which cause that nobody dares to call a spade a spade, when dealing with clearly protectionist state measures, shrouded in a thinly disguised public interest veil.

In 1994, the Court of Justice of the EU declared that games of chance relate »to a »service« within the meaning of Article (57) of the Treaty and accordingly fall within the scope of Article (56) of the Treaty « ${ }^{1}$ It is nevertheless widely accepted that these are by far not an ordinary kind of services. The positive sides of gambling are reflected in lower unemployment in the local community, the development of tourism and an increase in tax income (Grinols, 1996: 7-11; Thompson, 2012: 1-15; Walker, 2001: 177-183). However, the negative impacts of gambling, as described in the literature, include an increase in criminal activity, an increased number of divorces and family breakups, gambling addiction and changed values in the local community (Frank, 1991: 249-254). These pernicious effects of gambling have been thoroughly described by Dostoyevsky in his novel »The Gambler« (1866). Dostoyevsky would know as in the 1860 «s he gambled away much of his fortune, leaving him unable to pay his bills or afford proper meals. It is thus understandable

\footnotetext{
1 Case C-275/92, Her Majesty«s Customs and Excise v Gerhart Schindler and Jörg Schindler, ECLI:EU:C:1994:119, para. 37.
} 
that gambling authorities, responsible both to fill the public coffers and to protect the people, try to maximise the economic benefits of gambling while simultaneously attempting to minimize its injurious aspects.

With the rise of online gambling, however, new challenges arise, both for national and EU regulators in the field (Laffeym, 2016). The Internet is very convenient in this respect as gambling is almost always dependent upon a large group of participants, who put their stakes into the game. The larger the group, the larger the prize and vice versa - the larger the prize, the more people will participate in the group. The Internet makes it significantly easier to bring together more people, who participate in lotteries, betting etc. and since the Internet is not burdened by territorial frontiers, EU-wide games of chance are a very logical consequence for gambling providers to offer. Online gambling is thus a fast growing service activity in the EU. According to the EGBA recent figures, online gambling had a $20.7 \%$ share of the total EU gambling market activity, while $79.3 \%$ was land-based, including lotteries, casinos and bookmaker shops. The online share of the gambling market is expected to grow to $24.9 \%$ in 2020 . Sports betting $(40.3 \%)$ was the most popular form of online gambling in Europe, followed by casino games $(32.1 \%)$, lottery $(13.3 \%)$, poker $(6.1 \%)$, bingo $(4.6 \%)$, and other games $(3.6 \%)$. The economic size (or gross profit) of the EU online sector is expected to rise from 19.6 billion euro in 2017 to 24.7 billion euro in 2020 (EGBA Publishes EU Online Gambling Key Figures For 2017, 27 November 2018, Press Release).

H2 Gambling Capital (gaming and betting consultancy). The economic significance of the sector is also manifested both by the high level of innovation of the EU industry and the increasing amount of tax revenues generated in the Member States. The fast pace of online technologies development in recent years has facilitated the provision of gambling services through diverse remote distribution channels. Consumers in Europe also search across borders for online gambling services.

These foreign companies providing gambling services are not, however, fully embraced by the authorities (and competitors) on the host Member States markets. In an attempt to both protect the domestic providers and ensure that tax revenues from the stakes provided by their residents are not siphoned from the domestic budget, Member States try to restrict foreign providers from online gambling. These efforts are, however, only conditionally acceptable from the perspective of the single EU market. The present paper explores the admittedly difficult demarcation line between permissible restrictions on online gambling and the ones that are overly protectionist and restrictive. As this paper will demonstrate, this demarcation line remains frustratingly ambiguous, and that the EU Court«s casuistic approach is therefore not the best one to set legal certainty in the field. 


\section{Organisation of games of change - an unwelcome occupation}

Although the gambling industry argues that its products are simply a form of entertainment, like going to a cinema or football games, many researchers argue that gambling is fundamentally different from other forms of entertainment. Gaming is a specific economic sector as it presents a mixture of economic benefits and social costs unlike any other sector (Walker, Barnett, 1999: 181-212; Wynne, Shaffer, 2003: 111-121; Abott et al., 2004). ${ }^{2}$ A clear list of economic benefits and social costs gaming brings for a local community was made by Grinols (2004). According to him, the positive effects of gaming can be divided into the following categories:

- Economic development - one of the main arguments for gaming is that it has a beneficial influence on economic development. Economic development means an increase in income and welfare that leads to increased utility of all the members of society.

- Lower unemployment- Grinols claims that in the short run casinos have a beneficial effect on economic development, mainly through increased employment.

- Increased profits and taxes - besides the profits and taxes of the casinos themselves we have to take into account benefits bestowed upon nearby businesses. Casinos give business to lots of other companies - their suppliers and thus increase their profits. Consequently, the taxes the state and local authorities collect are also higher. The more the business goes to local companies, the better off the local community is.

- Benefits of closeness - the benefits of closeness are greatest when the first casino is opened in a certain area. The benefits accrue to individuals that wish to gamble (Walker:2001).

- Other benefits - including promotion of local community (especially in the case of export-oriented gambling), increased real estate values, and increased quality of life (higher income, closeness). Increased revenue from tourism is mentioned as a possible benefit (Grinols, 2004; Grinols and Omorov, 1996; Thompson, 2012).

\footnotetext{
${ }^{2}$ Markandya and Pearce (1989: 1138-1150) divide the costs and benefits that gambling brings to a local community into costs and benefits, that accrue to an individual and costs and benefits of the society (total costs $($ benefits $)=$ private costs $($ benefits $)+$ social costs $($ benefits $))$. Private costs and benefits are the costs that accrue to an individual and are covered by an individual. The social costs on the other hand have to be covered by all members of the society.
} 
On the other hand, Grinols classifies social costs as follows:

- Crime - criminal activity is mostly connected to problem and pathological gambling and consequent debts. ${ }^{3}$ Gaming is connected with different criminal activities, mostly violence (murders, robbery, rape, etc.), property damage (theft, thievery, etc.), economic crime (forgery, fraud, tax evasion, etc.) and prostitution (see also Meyer, Hayer and Griffiths, 2009).

- Treatment of problem and pathological gamblers - it is estimated that problem and pathological gamblers tend to get sick more often than the general population. It is also estimated that the costs of mental treatment of a problem gambler are more or less equal to the costs of treating an alcoholic; the difference is in the probability of getting treated (more in Griffiths, 1996 and 2000; Meyer and Stadler, 1999).

- Family breakups - Grinols argues that the divorce rate between problem gamblers is much higher than in general population.

- Suicides - empirical studies show that the suicide rate between problem gamblers is much higher than in the general population (Lesieur, 1998; Frank, Leister, Wexler, 1991: 249-254).

- Personal bankruptcies - Grinols states that personal bankruptcies cause direct costs as well as legal ones. Stitt et al. (2001) argue that the bankruptcy rate is connected to gambling.

- Business costs - among business costs associated with gaming studies show that problem gamblers cause their employers to lose money due to their lower productivity and higher absenteeism (Collins, Lapsley, 2003: 123148);

- Other costs - here Grinols refers to the costs of diminished disposable income of the population of gamblers. Other authors mention the costs of gaming regulations, increased costs of living, diminished quality of life, etc.

For reasons of these broad negative implications of gambling, both for the individual gambler as well as for the society as whole, gambling (or maisir) is prohibited in Islam. ${ }^{4}$ Although it is not strictly prohibited in Christianity or Catholicism, these religions argue that one should gamble with money they can afford to lose, and not view it as a source of income. ${ }^{5}$

It is not just religions that consider gambling with suspicion; legal systems do as well. In the EU, organisation of games of chance is in principle prohibited by the legal systems of all of its Member States. At the same time, most legal systems in

\footnotetext{
${ }^{3}$ Lesieur (2002) argues that players with a gambling problem spend 17 times as much money as players without a problem, while Grinols (2004) states that income from problem and pathological gamblers represents one third of the total revenue of a casino.

${ }^{4}$ It is stated in the Quran, the holly book of Islam, that intoxicants and games of chance, including maisir, were »abominations of Satan«s handiwork, « intended to turn people away from God and forget about prayer, thus Muslims were ordered to abstain from them - Qur«an, Sura 5: 90-91.

${ }^{5}$ Catechism of the Catholic Church, The Seventh Commandment, para. 2413 -

http://www.vatican.va/archive/ccc_css/archive/catechism/p3s2c2a7.htm (19 November 2018).
} 
Europe permit certain derogations to this a priori prohibition. The central historical reason for this is that complete prohibition has proven ineffective and has led to illegal and completely uncontrolled organisation of games of chance (more in McMillen, 2007). EU Member States have thus realised that it is better to have strict state control over organization of the games. (more on this in Spindler, Hambach, Berberich, 2011). In 2001 the German Federal Constitutional Court concluded that "the work of a casino on the whole is an unwelcome occupation that is nonetheless permitted by the government to check illegal gambling, to provide state-supervised opportunities for the human gaming instinct which cannot be restrained, and thereby to protect the natural passion for gambling from punishable exploitation « (ruling of 19 July 2001, cited in Meyer et al.: 2009: 86). Furthermore, Advocate General Bot stressed in Liga Portuguesa ${ }^{6}$ that the advantages of free competition for the consumers »do not arise in the area of games of chance and gambling. (...) Games of chance and gambling, for their part, can only function and continue if the great majority of players lose more than they win. Opening the market in that field, which would increase the share of household budgets spent on gaming, would only have the inevitable consequence, for most of them, of reducing their resources."

At the EU summit in Edinburgh in 1992, the European Council decided not to regulate gambling at the EU level, as it found that gambling, given the principle of subsidiarity, is unsuitable for community legislation and is better, or at least easier, dealt with at a national level. Based on this conclusion, the European Commission withdrew its plans to regulate gambling at the EU level and gambling remained a quasi-exclusive competence of the Member States, subject however to the full respect and observance of the fundamental principles of EU law (European Lotteries, Position Paper, 2004). Gambling is therefore not regulated at the EU level, but at the national level. All of the Member States have imposed strict limitations on gambling activities. In addition to the illegality of gambling activities that are offered in the EU, but which have not received a license in that country, Member States have the right to prohibit or restrict games offered from other EU Member States, even if provided by means of information society (Internet, interactive television, mobile betting).

From the perspective of free movement of services, three cross-border situations arise in respect of gambling:

a) situations where gamblers physically move to the Member State of the provider of games of chance, e.g. when they visit a casino in another EU Member State, either as part of a longer stay or only with the purpose of visiting the casino. In this situations, their home Member States have practically no possibilities of restricting their participation in gambling in the host Member State;

b) situations where providers of games of chance try to penetrate into another EU Member State market for offline provision of gambling. Almost all EU Member States have tried to avoid this by way of strict concession regimes

\footnotetext{
${ }^{6}$ Case C-42/07, Liga Portuguesa de Futebol Profissional and Bwin International Ltd v Departamento de Jogos da Santa Casa da Misericórdia de Lisboa, ECLI:EU:C:2008:560, para. 245-249.
} 
that lead to the exclusion of foreign gambling providers. Case law of the EU Court of Justice is intertwined with questions in respect of this line of restrictions;

c) situations where neither the gamblers, nor gambling providers physically move to another EU Member State, but still engage in gambling activities with the assistance of the Internet. Although EU Member States treat such gambling opportunities that address their citizens in the same way as offline providers, borderless Internet challenges such regulatory attempts in many ways, both in respect of inventiveness of the gambling providers, as well as gamblers, whose physical location is nowadays hard to be determined.

Various approaches by the Member States and the lack of harmonisation at the EU level in this field lead to regulatory competition between the Member States and to a race for gambling market shares. In the recent years, however, Member States have been under strict scrutiny of the European Commission and the Court of Justice of the EU as regards the consistency of national gambling laws with the internal market freedoms. There is an increasingly long line of cases in which the Court was asked to consider the legitimacy of the national measures restricting import of gaming into the Member States. This case law does not strictly distinguish between the three cross-border situations of gambling mentioned above, as for all of them Article 56 TFEU applies in equal terms, so that it is usually irrelevant, whether it was about online or offline gambling. Nevertheless, considering that restricting gamblers from physically going to another Member State for purpose of gambling is practically impossible, that concessions are mostly already awarded to the domestic gambling providers so that new providers hardly enter new markets for offline gambling, the Internet paves the way for new forms of gathering gamblers from a broader territory together. Consequently, the case law of the Court mostly concerns online gambling. As this form of gambling also brings important new challenges in respect of consumer protection, it is at the heart of the concerns in this field.

As EGBA figures show, over 12 million Europeans had an active online account for gambling. The average return to player/pay-out rate was $93.06 \%$ to the customers, which means that an average customer received 9.30 euro return for every 10 euro they bet. Customers placed a bet on average every 17 days with EGBA companies and an average customer spent 10 euro each time they placed a sports bet (EGBA Publishes EU Online Gambling Key Figures For 2017, 27 November 2018, Press Release). 
74 \begin{tabular}{l|l} 
LEXONOMICA \\
J. Hojnik: Online Gambling under EU Law: Strolling Between Controlled Expansion and \\
Genuine Diminution of Gambling Opportunities
\end{tabular}

\section{Balancing approach of the Court}

Despite the European Council«s decision to withdraw EU«s competences in the field of gambling the Court nevertheless has often intervened in the area. In its gambling case law, the Court has investigated to what extent national authorities may impose restrictions on the cross-border provision of gambling services and whether these restrictions are compatible with the Treaties.

\subsection{Reserved beginnings}

\subsubsection{Cross-border games of chance are services within the meaning of the TFEU}

The first relevant case on gambling concerns Gerhart and Jörg Schindler, ${ }^{7}$ who were independent agents of the German Lottery. They were dispatching envelopes containing lottery tickets from the Netherlands to the United Kingdom, which were confiscated by the authorities of the latter. Their activities breached British legislation prohibiting the import of objects related to drawing, lottery etc. The Schindlers argued that this national legislation breached Articles 34 and 56 TFEU. When questions for preliminary rulings were referred to the Court, several Member States expressed their position in support of the UK, stating that the legislation at hand was in line with EU law. The Court held that lottery activities are »services« within the meaning of Article 57 TFEU, considering that they are normally provided for remuneration (price of the ticket). This conclusion was not compromised by the chance character of the lotteries; nor by the fact that participation in them may be recreational only; nor even by the fact that profits arising from a lottery may generally be allocated in the public interest. The Court disagreed that rules on free movement of goods should be applied, as the case included cross-border sending and distribution of material objects necessary for their organization. The movement of goods was thus only of an ancillary nature to the provision of services, which were provided by the lottery operator, and which enabled the purchasers of tickets to participate in a game of chance with the hope of winning (para. 27). The Court admitted that games of chance are subject to strict regulation and close control by the public authorities in the various Member States. However, they are not totally prohibited (even in the UK small-scale lotteries for charitable and similar purposes were permitted) and are not by their nature the type of illegal products (e.g. drugs), needing such prohibition at the EU level.

\subsubsection{Restrictions on cross-border gambling may be justified}

While lotteries are services within the meaning of Article 57 TFEU, given their peculiar nature, Member States could nevertheless restrict or even prohibit lotteries from other Member States, provided those restrictions are not discriminatory on the basis of nationality. Moreover, the Court also laid down the objectives that it was prepared to accept as justifying restrictions on Article 56 TFEU. The Member States

\footnotetext{
7 Case C-275/92, Her Majesty«s Customs and Excise v Gerhart Schindler and Jörg Schindler, ECLI:EU:C:1994:119.
} 
submitted to the Court various arguments about overriding goals in public interest, which are protected by the restrictive legislation on games of chance. The Court admitted in Schindler that there are general moral, religious or cultural aspects of lotteries, which require national restrictions; it has confirmed the high risk of fraud and other forms of criminal activities that are associated with gambling activities given the size of the amounts which can be staked (para. 60; see also Meyer and Stadler, 1999 and Marionneau, 2015). Lotteries are also an incitement to spend, which may have damaging individual and social consequences and finally, despite being an economic reason and thus not an objective justification, the Court nevertheless emphasised that lotteries may make a significant contribution to the financing of benevolent activities such as social works, charitable works, sport or culture. The Court therefore stated that restrictions that were based on overriding public interest considerations (Schindler, para. 57)

"prevent crime and to ensure that gamblers would be treated honestly; to avoid stimulating demand in the gambling sector which has damaging social consequences when taken to excess; and to ensure that lotteries could not be operated for personal and commercial profit but solely for charitable, sporting or cultural purposes « could not be regarded as measures involving an unjustified interference with the freedom to provide services. These restrictions namely concern the protection of the recipients of the service and, more generally, of consumers as well as the maintenance of order in society (Schindler, para. 58).

Despite the fact that the Schindler case specifically concerned a lottery, the Court soon recognised that the established rules were applicable also to other types of games of chance - slot machines, bets etc. In this sense there is, however, one case, which stands out - i.e. Familiapress $v$ Bauer Verlag, ${ }^{8}$ where the Court declined to treat certain games in the same manner as the lotteries that were at the heart of the case in Schindler. The Familiapress case concerned competition among magazines, which included crosswords and other types of puzzles, where the readers - sending in the correct solution - were entitled to be entered in a drawing for prizes. The Court decided that such drawings do not significantly impact the public order, considering their small scale, which (quite surprisingly perhaps) according to the Court excludes their economic nature. Instead, they are merely one aspect of the broader editorial content of a magazine, which is protected by the freedom of expression (Familiapress, para. 23). This conclusion is rather unusual, since various kinds of raffles or tombolas are often not of a large scale. Nevertheless, the distinction the Court drew regarding prize winnings resulting from crosswords and other similar puzzles, on the one hand, and other types of gaming activities, is still understandable: the former primarily stimulate the search for answers on various questions and usually do not lead to detrimental addiction of players, which would lead to excessive spending and consequently threaten their and their families « existence. For this legitimate reason, these much less vulnerable games do not need

\footnotetext{
${ }^{8}$ Case C-368/95, Vereinigte Familiapress Zeitungsverlags- und vertriebs GmbH v Heinrich Bauer Verlag, ECLI:EU:C:1997:325.
} 
such strict state control as other forms of games of chance (for a more detailed commentary on the Schindler ruling see Hatzopoulos, 1999: 841).

After the renowned Schindler case the Court of Justice received several more cases requiring clarification of the rules on legal status of games of chance in the Community. We turn to these cases in the following sections.

\subsubsection{Restricted licences to protect individuals and the society}

In the case Lä̈̈r $\ddot{a},{ }^{9}$ the Court interpreted EU law in light of questions of the legitimacy of the Finnish State monopoly on the operation of slot machines (more on this in Örnberg, Tammi, 2011). Mr Läärä was prosecuted for providing slot machines deriving from a British company without a licence in Finland. Contrary to the Schindler case, the Court recognised in this case that the slot machines constituted goods, which may be imported and exported. Therefore, EU rules on free movement of goods had to be interpreted.

In this regard, the Court concluded that granting a licence to manage slot machines only to one operator in fact hinders the free movement of goods between the Member States. Nevertheless, the Court accepted the argument that a closed licensing system, which grants only one or a limited number of State owned and State controlled licensee(s), fulfil(s) all the requirements necessary in order to obtain an exception to the Community freedoms. The Court also pointed out that "given the risk of crime and fraud « there are no alternatives (such as taxation, to ensure that the funds collected are used for the public good) to a non-profit making approach that are equally effective to ensure »that strict limits are set to the lucrative nature of such activities ${ }^{10}{ }^{10}$

The Court also emphasised, regarding the manner in which lotteries are operated, that the national authorities have a sufficient degree of latitude to determine what is required not only to protect the players « interests but also to maintain order in society. The Court declined to assess the issues of whether it is necessary to restrict the activities of lotteries and also whether they should be prohibited. These questions are therefore for the Member States to decide, provided that those restrictions are not discriminatory. ${ }^{l 1}$

The Court added that the mere fact that an EU Member State has opted for a system of protection which differs from that adopted by another Member State cannot affect the assessment of the need for, and proportionality of, the provisions enacted to that end. Those provisions must be assessed solely by reference to the objectives pursued by the national authorities of the Member State concerned and the level of protection which they want to provide.

\footnotetext{
${ }^{9}$ Case C-124/97, Markku Juhani Läärä, Cotswold Microsystems Ltd and Oy Transatlantic Software Ltd v Kihlakunnansyyttäjä, ECLI:EU:C:1999:435.

${ }^{10}$ Läärä, para. 41.

${ }^{11}$ Läärä, para. 14.
} 
Nevertheless, it may be deducted from more recent case law, that the States may not give or renew gambling licences without inviting any competitive bids (more in Straetmans: 2000). The Court namely stated that »the complete failure to invite competing bids for the purposes of granting licences for horse-race betting operations does not accord with Articles (49) and (56 TFEU), and, in particular, infringes the general principle of transparency and the obligation to ensure a sufficient degree of advertising " (Commission v Italy ${ }^{12}$ ).

\subsubsection{Italian gambling legislation - first time}

Italian legislation on games of chance has become the cornerstone of the Court of Justice«s analytical framework when establishing EU rules on cross-border gambling. There is a whole series of cases where the Italian authorities referred for preliminary rulings on gambling issues. The first case in this series was Zenatti. ${ }^{13}$

According to the material Italian legislation, taking bets was prohibited, with the exception of bets on races, regattas, ball games and other similar contests where the taking of bets is essential for the proper conduct of the competitive event. The Financial Act of 2000 expressly provided that the organisation of bets was in the exclusive competence of those possessing a licence or those having the permission of a ministry. Under the Financial Act, Bets could only be placed on the outcome of sporting events taking place under the supervision of the Italian Olympic Committee or on the results of horse races organised though the National Union for Horse Breeds (UNIRE). Accordingly, it was prohibited for foreign bets operators to accept the bets of Italian consumers.

Mr. Zenatti has acted as an intermediary in Italy for the London company SSP Overseas Betting Ltd. He ran an information exchange for the Italian customers of SSP in relation to bets on foreign sports events. He sent to London, by fax or Internet, forms which were filled in by customers, together with bank transfer forms, and received faxes from SSP for transmission to the same customers. In 1997, however, the Questore di Verona ordered Mr. Zenatti to cease that activity on the ground that it breached Italian legislation.

The Court has emphasised that freedom of establishment was potentially breached by the relevant Italian law; ${ }^{14}$ nevertheless, the Court then concentrated on free movement of services, which was prima facie hindered. However, both the Advocate General and the Court recognised that restrictions on the provision of betting services could be justified on the grounds of public interest concerns, which should reflect the diverse characteristics of each Member State, including their social and cultural attitudes towards gambling. They found the Italian legislation endorsed objectives similar to the British legislation, which were considered in Schindler. However, the Italian legislation pursued these goals in a different manner than the British legislation did. The latter namely involved a total prohibition of

\footnotetext{
${ }^{12}$ Case C-260/04, ECLI:EU:C:2007:508.

${ }^{13}$ Case C-67/98, Questore di Verona v Diego Zenatti, ECLI:EU:C:1999:514.

${ }^{14}$ Zenatti, para. 22.
} 
large lotteries, whereas the legislation at issue in Zenatti did not totally prohibit the taking of bets but instead reserved to certain bodies the right to organise betting under certain circumstances.

This distinction among the two cases, however, had no legally relevant consequences. The Court namely concluded that "determination of the scope of the protection which a Member State intends providing in its territory in relation to (...) gambling falls within the margin of appreciation enjoyed by the national authorities «. ${ }^{15}$ In this sense, a decision for a different system of protecting the public interest, as might be in place in another Member State, does not affect the appraisal of the need for, and proportionality of, the restrictive measure. ${ }^{16}$

The Court added, however, that such a limitation is acceptable only if it reflects an actual concern of bringing about a genuine diminution in gambling opportunities and if the financing of social activities constitutes only an incidental beneficial consequence and is not the real justification for the restrictive policy adopted. ${ }^{17}$ This aspect of the Court«s decision was further explained in the following case-law.

Hopes that the Court would adopt a more liberal stance towards the issue of crossborder gambling were again raised when the case of Gambelli $^{18}$ came before the Court.

\subsection{Quasi-liberal continuation}

\subsubsection{Italian gambling legislation - second time}

Gambelli and others had been acting as agents for Stanley International Betting Limited, an arm of a UK betting concern. ${ }^{19}$ Criminal sanctions were taken against them, on the grounds that their activities contravened Italian law, which forbade concerns that were not licensed in Italy from accepting bets from Italian citizens. In

\footnotetext{
${ }^{15}$ Zenatti, para. 33.

16 Zenatti, para. 33-34. Also in a Portuguese case Anomar (case C-6/01, Associação Nacional de Operadores de Máquinas Recreativas (Anomar) and Others v Estado português, ECLI:EU:C:2003:446, para. 80) the Court found that »the mere fact that a Member State has chosen a system of protection different from that adopted by another Member State cannot affect the appraisal as to the need for and proportionality of the provisions adopted. They must be assessed solely in the light of the objectives pursued by the national authorities of the Member State concerned and of the level of protection which they seek to ensure". Anomar, the Portuguese national association of operators in the gaming machine sector et al, had challenged the efficacy of a decree that stated that the right to operate games of chance or gambling in Portugal is reserved to the State. The Court, however, upheld the right of the state to operate a monopoly.

${ }^{17}$ Zenatti, para. 36.

${ }^{18}$ Case C-243/01, Criminal proceedings against Piergiorgio Gambelli and Others, ECLI:EU:C:2003:597.

${ }^{19}$ The bets were performed as follows: the bettor notifies the person in charge of the Italian agency of the events on which he wishes to bet and how much he intends to bet; the agency sends the application for acceptance to the bookmaker by internet, indicating the national football games in question and the bet; the bookmaker confirms acceptance of the bet in real time by internet; the confirmation is transmitted by the Italian agency to the bettor and the bettor pays the sum due to the agency, which sum is then transferred to the bookmaker into a foreign account.
} 
his defence, Gambelli and others claimed that the Italian law contravened both the freedom of establishment and the freedom to provide services.

The most important support for their assertions derived from parliamentary materials for a new (more restrictive) legislation of 2000, which substantiated that the purpose of the new legislation was to protect a category of private sector undertakings Totoricevitori - and not public interest goals. In addition, the national court could not ignore the extent of the apparent discrepancy between national legislation severely restricting the acceptance of bets on sporting events by foreign Community undertakings on the one hand, and the considerable expansion of betting and gaming which the Italian State is pursuing at national level for the purpose of collecting taxation revenues, on the other. For this reason, a reference for preliminary ruling was made.

The Advocate General Alber issued, according to many, a surprising opinion. The main aspect of the opinion concerns an assessment of whether the Italian legislation genuinely tries to limit gambling passion. In this regard, the Advocate General considered it unacceptable that sports betting operators trading under a concession make themselves known by means of aggressive advertising, which is intended to instil and foster a desire to gamble. In addition to this, the Italian State not only has made it possible to substantially extend the range of gambling opportunities available on the Italian market but also has made it easier to collect bets. On the basis of this, he said there can no longer be any talk of a coherent policy to limit gambling opportunities. Thus, he concluded that the objectives professed, but not in reality pursued, are not adequate justifications for the restrictions placed upon the freedom to provide services. ${ }^{20}$ Italy`s move to liberalise its own gaming market has therefore led the Advocate General to a conclusion that the Italian law could not be justified and was purely discriminatory against bookmakers from other countries.

This opinion was considered by many as revolutionary in the EU law, despite being completely in line with the established case law of the Court. The only novelty in this regard lies in the fact that the Advocate General has not left it to the national court to appraise, whether public interest goals, asserted by the Italian legislation, were genuine.

The Court has supported the Advocate General in his practically more realistic approach and has emphasised that ${ }^{21}$

»In so far as the authorities of a Member State incite and encourage consumers to participate in lotteries, games of chance and betting to the financial benefit of the public purse, the authorities of that State cannot invoke public order concerns relating to the need to reduce opportunities for betting in order to justify measures (...)."

\footnotetext{
${ }^{20}$ Opinion of the Advocate General in Gambelli, para. 122.

${ }^{21}$ Gambelli, para. 69.
} 
In contrast to the Advocate General's conclusions, however, the Court left it to the national court to decide whether the conditions for objective justification of free movement barriers are met. Nevertheless, the national courts are bound by the guidelines of the Court. In this sense the Court stated that where a criminal penalty is imposed on any person who, from his home in a Member State, connects by Internet to a bookmaker established in another Member State, the national court must consider whether this constitutes a disproportionate penalty. Moreover, the Court has already signalled its own conclusion on this issue, by stressing that there is a restriction on free movement in place, accompanied by criminal penalties of up to one year's imprisonment and that on the other hand we have a supplier of the service, who is subject in his Member State of establishment to a regulation entailing controls and penalties, and intermediaries, who are lawfully constituted and their activities being permitted before the last statutory amendments (para. 73). Despite these instructions, the national courts are in the unenviable position of carrying out a detailed (economic) assessment in the light of national political objectives and the principle of proportionality, which they are unlikely to feel comfortable in doing (Straetmans, 2004).

In a wave of approvals as regards the limitations of state discretion in the field of gambling expressed by European federal lawyers, one week after the Gambelli ruling the Court issued a new judgement in a taxation case, where it confirmed its conclusions in Gambelli.

\subsubsection{National tax autonomy and cross-border gambling}

The Lindman decision ${ }^{22}$ is an important precedent in the harmonisation of taxation rules for gambling businesses within the EU. The case had revolved around a Finnish national Diane Lindman, who had won a million of Swedish Krons in a Swedish lottery, whilst in Sweden, and the decision of the Finish Government to tax her on those winnings.

The Advocate General Stix-Hackl concluded, that in so far as the winnings would have been tax free if they had been won on a Finish Lottery, a decision to tax them in Finland purely on the grounds that they had been won in Sweden, ran contrary to the spirit of the freedom to provide services, and indeed, restricted this fundamental freedom, without any justification. The Finish Government had argued that the restriction was justified on the grounds that it would assist in the control of both compulsive gambling and money laundering. Stix-Hackl, however, relying upon the proportionality test, concluded that the measure was disproportionate to the objectives being pursued.

The Court was relatively brief in its judgment, emphasising the established principle of national tax autonomy, which is, however, limited by the fundamental economic freedoms. It was evident that the Finnish tax legislation was discriminatory towards foreign games of chance in comparison to the domestic ones. The Government's

\footnotetext{
${ }^{22}$ Case C-42/02, Diana Elisabeth Lindman, ECLI:EU:C:2003:613.
} 
defence, that gaming providers established in Finland are nevertheless subject to tax as organisers of gambling, did not change the Court's finding of (manifest) discrimination, since that tax is not analogous to the income tax charged on winnings from taxpayer`s participation in lotteries held in other Member States. ${ }^{23}$

As regards justifications for such discriminatory tax legislation, the Court agreed that it is legitimate to take into consideration the damaging consequences of gambling addiction, which is a matter of public health (need for rehabilitation centres and social problems, such as depriving of resources the families of gambling addicts, divorce, and suicide). However, the Court emphasised that these stated objectives must be accompanied by an analysis of the appropriateness and proportionality of the restrictive measure adopted by that State (in line with the Court's decision in Oteiza Olazabal ${ }^{24}$ ). In this regard, the Court asked for statistical or other evidence which would lend objective, verifiable support to any conclusion as to the gravity of the risks connected to playing games of chance or, a fortiori, the existence of a particular causal relationship between such risks and participation by nationals of the Member State concerned in lotteries organised in other Member States. ${ }^{25}$ Since no such was evidence submitted, the Court adhered to the Advocate General's conclusion that legislation under which winnings from games of chance organised in other Member States are taxed, whereas winnings from games of chance conducted in the Member State in question are not taxable, breaches Article 56 TFEU (Straetmans, 2004).

Even after the Lindman judgment, some Member States continue to grant preferential tax treatments to domestic lottery winnings over prizes won on foreign games. For example, the Spanish tax legislation is being closely monitored by the Commission, which is able to rely on a strong precedent set by the Court in any infringement proceedings it initiates.

\subsection{Diverse national responses to the judgments in Gambelli and Lindman}

Analyses of the national jurisprudence in the field of gambling after the Gambelli and Lindman judgments of the Court have shown that the requirements of those two judgments were applied in a very diverging manner (Keuleers, 2005):

- the German Bundesgerichtshof (BGH) held that the editor of an online newspaper could not be held liable for inserting a link to an Austrian licensed bookmaker; furthermore, the BGH explicitly questioned whether the current German gaming policy could be reconciled with the requirements of the EU law;

- in the Netherlands certain lower courts required proof of a consistent gaming policy, whereas on the other hand in the so-called Betfair appeal

\footnotetext{
${ }^{23}$ Lindman, para. 22.

${ }^{24}$ Case C-100/01, Ministre de l«Intérieur v Aitor Oteiza Olazabal, ECLI:EU:C:2002:712.

${ }^{25}$ Lindman, para. 26.
} 
case it was insinuated that Gambelli was not relevant (the case was later referred to the Court - Sporting Exchange (Betfair ${ }^{26}$ );

- in Spain, the Loterías y Apuestas del Estado (LAE) maintained its position that it has the exclusive right to offer and promote games on the Internet;

- in Italy, the Supreme Court`s April 2004 ruling in Gesualdi went directly against the Cour`s Gambelli decision: the Supreme Court found that as the restrictions justified a public order interest (keeping gambling free from criminality), they did not constitute a restriction on the freedom of establishment and the freedom to provide services, despite the restriction`s obvious purpose of promoting a policy of expansion in the betting and gaming sector with the manifest aim of increasing tax revenue of the Italian legislature.

\subsection{Balance making}

\subsubsection{Italian gambling legislation - third time}

In view of the manifest contradiction between the Court of Justice case-law and the Italian Supreme Court's decision, the Tribunale di Larino referred the case to the former. In a case identical to Gambelli (only this time $\mathrm{Mr}$ Placanica was prosecuted $^{27}$ ), the Larino District Court questioned whether the Italian gaming restrictions as interpreted by the Supreme Court can be reconciled with the single market principles as interpreted by the Court. The Court`s judgment in Placanica represents a further step on the road towards the full liberalisation of the crossborder gambling in the EU, especially as betting is concerned. Nevertheless, to a large, extent the Court still follows its previous rulings in Schindler, Läärä, Zenatti and Gambelli. However, the judgment is stricter towards the Member States in certain respects (Littler, 2007; Littler, 2011; Del Ninno, 2007; Keuleers, 2005).

The Court expressly stated that a Member State may not apply a criminal penalty for failure to complete an administrative formality where, in breach of community law, such completion is refused or rendered impossible by that Member State. ${ }^{28}$ This means that where national gambling laws contravene with the EU law, that State may not resort to criminal sanctions against private gambling operators. Therefore, where a Member State continues to flaunt EU gambling law, through e.g. the blatant advertising of gambling services, that State is not entitled to exclude multinational companies (like BWIN, Ladbrokes and Sportingbet) from operating in its market.

In contrast to the Gambelli judgment, where the Court left it to the national court to decide issues of proportionality, the Court in Placanica simply decided that, independent of the question of discrimination, the blanket exclusion of companies quoted on the regulated markets goes beyond what is necessary in order to achieve, what the Court considered to be, the legitimate objective of preventing operators

\footnotetext{
${ }^{26}$ Case C-203/08, Sporting Exchange Ltd v Minister van Justitie, ECLI:EU:C:2010:307.

27 Joined cases C-338/04, Criminal proceedings against Massimiliano Placanica, C-359/04, Christian Palazzese, and C-360/04, Angelo Sorricchio, ECLI:EU:C:2007:133 (Placanica).

${ }^{28}$ Placanica, para. 69.
} 
active in the betting and gaming sector from being involved in criminal or fraudulent activities. ${ }^{29}$ The Court's approach clearly provides support to operators looking to challenge national concession regimes.

However, as regards justification for restrictive legislation, the Court re-affirmed its rulings in Zenatti and Gambelli, namely that restrictions on the number of operators can in principle be justified, to the extent those restrictions in fact (objectively) reflect a concern to bring about a genuine reduction of gambling opportunities and to limit the activities in that sector in a consistent and systematic manner. The Court, however, noted that the principal aim of the Italian legislation instead was merely to increase the State`s tax revenue and the Court confirmed its consistent jurisprudence that this aim in and of itself cannot justify a restriction to the freedom of establishment/to provide services. Nevertheless, the Court recognised another legitimate objective - that of preventing the use of betting and gambling activities for criminal or fraudulent purposes by channelling them into controllable systems. In that respect the Court remarked that (Placanica, para. 55)

»it is possible that a policy of controlled expansion in the betting and gaming sector may be entirely consistent with the objective of drawing players away from clandestine betting and gaming" and that "(t)his may as such necessitate the offer of an extensive range of games, advertising on a certain scale and the use of new distribution techniques".

It is indeed difficult to reconcile controlled expansion with a diminution in gambling opportunities; the former is namely in fact merely a protectionist measure pursuing economic purposes (revenue raising) and by the latter the Court is giving the States necessary words to disguise the former (Bogaert, Cuyvers, 2011). It is probably a question of degree, which will be judged on a case-by-case basis, when inciting and encouraging consumers to participate in games of chance will be in line and when contrary to (legitimate) public interest concerns.

\subsubsection{A broad margin of discretion to Member States to restrict provision of gambling}

One can certainly form an impression that the Court is offering a helping hand to the Member States currently defending their restrictive regulatory systems or at least making balance in positions between Member States (looking to isolate their national markets from competition) and gaming operators (looking to expand across the EU) (more on this in Azoulai, 2011).

And while some commentators are of the opinion that in the Placanica the Court put the "final nail in the coffin of the state-monopoly model in the gambling sector" (European Gaming and Betting Association, 2007), subsequent to this ruling there were new judgments of the Court that favour the monopolists. For example, the

\footnotetext{
${ }^{29}$ Placanica, para. 62 .
} 
Court rejected a claim by the private online gambling operator Unibet, ${ }^{30}$ that it should be granted immediate access to the Swedish betting market.

Also, Advocate General Bot has stressed in Liga Portuguesa ${ }^{31}$ that "Community law does not aim to subject games of chance and gambling to the laws of the market." He stressed that competition is a source of progress and development. However, these advantages do not arise in the area of games of chance and gambling, which can only function and continue if the great majority of players lose more than they win. He concluded by saying that: ${ }^{32}$

»limiting the powers of the Member States in the field of games of chance and gambling does not have the aim of establishing a common market and the liberalisation of that area of activity (and therefore) the Member States have a broad discretion in determining the degree of protection to be provided in relation to games of chance and gambling

The case concerned Portuguese legislation conferring on Santa Casa a monopoly for mutual betting on the Internet. Bwin, an on-line gambling undertaking established in Gibraltar, and the Liga Portuguesa de Futebol Profissional, had been fined for having offered games of chance via the Internet and having advertised them. These fines were based on Portuguese legislation which confers a monopoly on the institution called »Santa Casa« to manage such games within Portugal. The criminal court in Porto, before which Bwin and the Liga challenged these fines, referred questions to the Court on the interpretation of Article 56 TFEUC on the freedom to provide services. The Court found that national legislation which prohibits operators such as Bwin, which are established in other Member States, in which they lawfully provide similar services, from offering games of chance via the Internet, restricts the freedom to provide services. Nevertheless, such a restriction may be justified for overriding reasons in the public interest, such as the objectives of consumer protection, the prevention of both fraud and incitement to citizens to squander money on gambling, as well as the general need to preserve public order.

Following the reasoning of the Advocate General, the Court also emphasised that the legislation on games of chance is one of the areas in which there are significant moral, religious and cultural differences between the Member States (see more in Euchner, 2013). Games of chance involve substantial risks of crime and fraud, given the scale of the earnings and the potential winnings on offer to gamblers. In this light, and in the absence of Community harmonisation in the field, the Court pointed out that it is for each Member State to determine, in accordance with its own scale of values, what is required in order to ensure that the interests in question are protected. Member States therefore have a degree of freedom to set their policy objectives on betting and gambling and, where appropriate, to define in detail the level of protection sought. However, the restrictive measures that they seek to impose must

30 Case C-432/05, Unibet (London) Ltd and Unibet (International) Ltd v Justitiekanslern, ECLI:EU:C:2007:163.

${ }^{31}$ Case C-42/07, ECLI:EU:C:2008:560.

${ }^{32}$ Opinion of Advocate General Bot in Liga Portuguesa, paras. 245-249 and 265. 
be both necessary and proportionate to achieve the objectives pursued and must also be applied without discrimination. The Court recalled that the objective of combating crime invoked by Portugal may constitute an overriding reason in the public interest that is capable of justifying the restrictions in question. Granting exclusive rights to operate games of chance via the Internet to an operator such as Santa Casa may confine the operation of gambling to controlled channels and was regarded by the Court as appropriate for the purpose of protecting consumers against fraud on the part of operators. Moreover, the Court added that because of the lack of direct contact between consumer and operator, games of chance accessible via the Internet involve more substantial risks of fraud by operators against consumers, compared with the traditional markets for such games.

Despite this judgment by the Grand Chamber of the Court, in the last ten years many more cases had been referred to the Court by the national courts to get advice on appropriate balance between free movement of services and protected aims in public interest that justify restrictions on games of chance offerings from other EU Member States.

The Court, in a series of cases, has issued judgments that provide Member States with broad discretion regarding legislation in the gaming field. By way of example, in Sporting Exchange (Betfair ${ }^{33}$ ) and in Ladbrokes International ${ }^{34}$ the Court confirmed the measure of discretion allowed to Member States with regard to legislation constituting a restriction on freedom of establishment or the freedom to provide services, in the specific field of games of chance, subject to the consistency of the legislation in question. In these two cases, which related to the compatibility of Dutch legislation on games of chance with Union law, the Court confirmed that national legislation prohibiting the offer of games of chance via the Internet to operators established in other Member States, where they lawfully provide similar services, restricts the freedom to provide services (more on this in Kingma, 2008). Nevertheless, such a restriction may be justified by overriding reasons in the public interest, such as consumer protection and the prevention of both fraud and incitement to squander money on gambling, as well as the general need to preserve public order. According to the Court, it is the duty of the national court in this capacity to check whether the illegal gaming activities may constitute a problem in the Member State concerned and whether expansion of the authorised, regulated activities could resolve this problem. This therefore implies that the objective invoked by the national authorities is real and of a scale which justifies recourse to a controlled expansion policy. The national court must also examine the existence of effective control of this »expansion« by the authorities of the Member State, which must not be excessive and compromise the objective generally sought of combating gambling addiction.

\footnotetext{
${ }^{33}$ Case C-203/08, Sporting Exchange Ltd v Minister van Justitie, ECLI:EU:C:2010:307.

${ }^{34}$ Case C-258/08, Ladbrokes Betting \& Gaming Ltd and Ladbrokes International Ltd v Stichting de Nationale Sporttotalisator, ECLI:EU:C:2010:308.
} 
The same line of reasoning was also adopted in SIA Garkalns v Rigas dome. ${ }^{35}$ There, the Court decided that Article 56 TFEU confers on local authorities a broad discretion in enabling them to refuse authorisation to open a casino, amusement arcade or bingo hall on grounds of »substantial impairment of the interests of the State and of the residents of the administrative area concerned «, provided that that legislation is genuinely intended to reduce opportunities for gambling and to limit activities in that domain in a consistent and systematic manner or to ensure the maintenance of public order and in so far as the competent authorities exercise their powers of discretion in a transparent manner. Again, it is for the national court to determine whether those conditions are satisfied.

In Digibet, ${ }^{36}$ the Court again reaffirmed that Member States have broad discretion in the field of regulating games of chance. The Court found that Article 56 TFEU does not preclude legislation common to the majority of the federal entities of a Member State having a federal structure, in this case Germany, which prohibits, in principle, the organisation and facilitation of games of chance via the Internet. In this case, for a limited period, a single federal entity has maintained in force more liberal legislation coexisting with the restrictive legislation of the other federal entities, provided that such legislation is able to satisfy the conditions of proportionality laid down by the case-law of the Court.

Moreover, in Biasci ${ }^{37}$ the Court interpreted Articles 49 and 56 TFEU as not precluding national legislation which requires companies wishing to pursue activities linked to gaming and betting to obtain a police authorisation, in addition to a licence issued by the State, in order to pursue such activities, and which restricts the grant of such authorisation, inter alia, to applicants who already hold such a licence. Furthermore, in Domenico Politano, ${ }^{38}$ the Court held that Article 56 TFEU does not preclude national legislation, which imposes on operators wishing to respond to a call for tenders for the grant of concessions in the field of betting and gambling, the obligation of providing evidence of their economic and financial standing by means of statements issued by at least two banks, without also allowing that standing to be proved by other means. Similarly, in Global Starnet, ${ }^{39}$ the Court interpreted Articles 49 and 56 TFEU and the principle of protection of legitimate expectations as not precluding national legislation which imposes on persons who are already concession holders in the sector of the online operation of legal gaming, new conditions for the exercise of their activity by means of an addendum to the existing agreement. Finally, in Stanleybet Malta ${ }^{40}$ the Court interpreted Articles 49 TFEU and 56 TFEU and the principles of equal treatment and effectiveness as not

\footnotetext{
${ }^{35}$ Case C-470/11, SIA Garkalns v Rīgas dome, ECLI:EU:C:2012:505.

${ }^{36}$ Case C-156/13, Digibet Ltd and Gert Albers v Westdeutsche Lotterie GmbH \& Co. OHG, ECLI:EU:C:2014:1756.

${ }^{37}$ Joined Cases C-660/11 and C-8/12, Daniele Biasci and Others v Ministero dell Interno and Questura di Livorno and and Cristian Rainone and Others v Ministero del'Interno and Others, ECLI:EU:C:2013:550.

${ }^{38}$ Case C-225/15, Criminal proceedings against Domenico Politanò, ECLI:EU:C:2016:645.

${ }^{39}$ Case C-322/16, Global Starnet Ltd v Ministero dell 'Economia e delle Finanze and Amministrazione Autonoma Monopoli di Stato, ECLI:EU:C:2017:985.

${ }^{40}$ Case C-463/13, Stanley International Betting Ltd and Stanleybet Malta Ltd v Ministero dell 'Economia e delle Finanze and Agenzia delle Dogane e dei Monopoli di Stato, ECLI:EU:C:2015:25.
} 
precluding national legislation, which provides for the organisation of a fresh call for tenders for the award of licences with a period of validity shorter than that of licences awarded previously because of the reorganisation of the system by way of an alignment of licence expiry dates.

As another example, a broad margin of discretion was also approved to Austria in respect of two Slovenian gambling providers. Austria considered that Slovenian regulation does not assure a similar level of protection of society against the negative effects of gambling to the Austrian one. In the case HIT, ${ }^{41}$ HIT and HIT LARIX operate casinos in Slovenia. The two companies applied for licenses to advertise their gaming establishments in Austria, but were denied. Austrian law provides that permits for advertising casinos located in other Member States can be granted only where the legal protection for gamblers in the casino`s State »at least corresponds to " the protection provided in Austria. The Austrian authorities found that Slovenian regulations were insufficient to meet this test, noting in particular the lack of a legal obligation to warn and bar gamblers who seem to be exceeding their limits; the lack of a monitoring system for gambling abuse; the lack of adequate legislation to protect minors; and, the lack of a provision for direct civil actions in case a gaming establishment breaches its obligations (more on this in Delfabbro and King, 2012).

The companies brought suit, alleging that Austria's refusal to allow their advertisements was in breach of the right to freely provide services under EU law. Austria argued that its restriction was justified by overriding reasons in the public interest-in particular, the protection of consumers. The Court found the Austrian regulation requiring comparable protections for gambling establishments to be a restriction on the freedom to provide services under Article 56 TFEU. However, it also found that the restriction was justified on public interest grounds. ${ }^{42}$ The Court in HIT and HIT LARIX thus held that a Member State may restrict advertisements for foreign casinos on the ground that the casino's home state does not provide equivalent protection for gamblers. However, they cannot require an identical regulation, and the restriction must be directly related to protecting consumers. The Court therefore held that a measure like Austria`s would be proportional so long as it required only an equivalent (but not identical) level of protection, and so long as it was directly related to protecting consumers against the risks of gambling.

Nevertheless, the disagreement over proportionality is evident in the differences between the opinion of the Court and that of Advocate General Mazák, who had argued that Austria`s rule "goes beyond what is necessary to achieve the objective of protecting consumers«. The Advocate General was concerned that the system of prior authorization for advertising could constitute ' $a$ »hidden « total prohibition of the advertising of foreign casino 's, and that it »leads, ultimately, to a discrimination based on the origin of the applicant «. Moreover, he was concerned with the fact that the grant of a permit »depends solely on the content of the legislation of the Member

\footnotetext{
${ }^{41}$ Case C-176/11, HIT hoteli, igralnice, turizem dd Nova Gorica and HIT LARIX, prirejanje posebnih iger na srečo in turizem dd v Bundesminister für Finanzen, ECLI:EU:C:2012:454.

${ }^{42}$ HIT and HIT LARIX, para. 36.
} 
State, without taking account of the actual level of protection provided by the casino operator ${ }^{43}$

The proportionality question is therefore the driving force behind the numerous references for preliminary rulings in the field of gambling, making it hard to establish legal certainty in respect of very diverse national circumstances surrounding particular legal systems of the Member States, their traditional origin, as well as distinct political choices of their legislatures as to how to respond to the unwanted providers of gambling from other EU Member States.

\subsubsection{Surprising knock-outs of some national systems of gambling control}

Uncertainty over the system of principles, developed by the Court in respect of applying Articles 49 and 56 TFEU to the national rules governing gambling, is evident from the fact that two years before the Court's decision in HIT, the Court ruled that certain provisions in the Austrian Gaming Act and "the total absence of transparency for the purposes of the grant of the concessions « to the Austrian defacto monopolist casino operator, Casinos Austria AG (»CASAG«), are contrary to EU law. The judgment confirms that the Member States may not require the gambling providers to be physically present on the territory of the respective Member States.

The Austrian Gaming Act (Glücksspielgesetz) established a state monopoly on lotteries and casinos. Only operators having been granted a license according to the Act were entitled to offer such gaming operations in Austria. At the time of the referral to the Court, the Act required a casino operator to be a publicly listed company with a seat in Austria and a share capital of EUR 22 million. All twelve licenses have been held by CASAG, to which the licenses had been awarded behind closed doors without any tender procedure. Furthermore, the licensing and supervising authority, the Ministry of Finance, is an indirect shareholder of CASAG through the participation of the state.

The German citizen Ernst Engelmann »operated gaming establishments in Austria [...]. In those establishments, he offered his customers, inter alia, a game called observation roulette and the card games Poker and Two Aces. He had not sought a concession to organise games of chance, nor was he the holder of a lawful authorisation in another Member State. "Therefore, he was charged according to the Austrian Criminal Code for offering games of chance without a national license. However, the court of appeal was in doubt of the conformity of relevant provisions of the Austrian Gaming Act with EU law, namely with the freedom of establishment (Art 49 TFEU) and the freedom to provide services (Art 56 TFEU).

It is important to note, that due to the Austrian regulations at stake, it was impossible for potential licensees from other Member States to acquire a license under Austrian law. The requirement of a seat and the lack of transparency were clear violations of

\footnotetext{
${ }^{43}$ Advocate General Mazák in HIT and HIT LARIX, paras 22-26.
} 
EU law. Consequently, in November 2010, the Austrian government issued a draft amendment of the Austrian Gaming Act as part of the budgetary bill, slightly redesigning one license requirement for the lottery and casino licenses. The purpose of the new draft amendment was to overcome violations of EU freedoms which were found by the Engelmann ruling. This amendment modified the requirement of having a seat in the operational phase to the effect that now a seat in any Member State is sufficient, if the potential licensee also has a »comparable license « from the Member State in which it is established or, in case of a successful application, the company founds its seat in Austria within a certain respite. Judging from the Court's previous case law, it may be concluded that the Austrian Gaming Act, even after these amendments, would still not be compliant with EU law and could ultimately result in the Court issuing a ruling similar to the one already delivered in the Engelmann case.

At least two additional judgments thus found the Austrian gaming law framework in contradiction with EU law. Firstly, on 15 September 2011 the Court held in Dickinger and $\ddot{O m e r}^{44}$ that EU law, in particular Article 56 TFEU, precludes the imposition of criminal penalties for infringing a monopoly of operating games of chance, such as the monopoly of operating online casino games, if such legislation is not compatible with EU law. And secondly, on 30 April 2014 the Court held in Pfleger and others ${ }^{45}$ that Article 56 TFEU precludes national legislation that does not actually pursue the objective of protecting gamblers or fighting crime and does not genuinely meet the concern of reducing opportunities for gambling or to fight gambling-related crime in a consistent and systematic manner.

Moreover, with respect to the Greek system of a monopoly, the Court held in Stanleybet $I^{46}$ that Articles 49 and 56 TFEU preclude national legislation which grants the exclusive right to run, manage, organise and operate games of chance to a single entity, where: a) that legislation does not genuinely meet the concern to reduce opportunities for gambling and to limit activities in that domain in a consistent and systematic manner and, b) where strict control by the public authorities of the expansion of the sector of games of chance, solely in so far as is necessary to combat criminality linked to those games, is not ensured. Stanleybet, William Hill and Sportingbet, companies with their registered office in the United Kingdom, where they hold bookmaker's licences, have therefore successfully challenged Greek Law, under which the exclusive right to run, organise and operate games of chance and betting forms with fixed or variable winnings was granted to OPAP for a period of 20 years.

Furthermore, with respect to the German regulatory system intended to control gambling activities on its territory, the Grand Chamber of the Court issued its

${ }^{44}$ Case C-347/09, Criminal proceedings against Jochen Dickinger and Franz Ömer, ECLI:EU:C:2011:582.

${ }^{45}$ Case C-390/12, Robert Pfleger and Others, ECLI:EU:C:2014:281.

46 Joined Cases C-186/11 and C-209/11, Stanleybet International Ltd, William Hill Organization Ltd, William Hill plc, Sportingbet plc v Ipourgos Oikonomias kai Oikonomikon Ipourgos Politismou, ECLI:EU:2013:33. 
judgment in three joined cases ${ }^{47}$ finding that the public monopoly of the organisation of sporting bets and lotteries in Germany does not pursue the objective of combating the dangers of gambling in a consistent and systematic manner. In Germany, jurisdiction over gambling is divided between the federal State and the Länder. In most of the Länder, there is a regional monopoly for the organisation of sporting bets and lotteries, while the organisation of bets on horse racing and the operation of gaming machines and casinos are entrusted to duly-authorised private operators. By the treaty on lotteries in Germany (Lotteriestaatsvertrag), which came into force on 1 July 2004, the Länder created a uniform framework for the organisation of games of chance, apart from casinos. Following a judgment of the Budesverfassungsgericht, that treaty was replaced by the treaty on games of chance in Germany (Glücksspielstaatsvertrag), which entered into force on 1 January 2008. The latter prohibited all organisation or intermediation of public games of chance on the Internet.

The company Winner Wetten has commercial premises at Bergheim, where it carries on the business of brokering bets on sporting competitions on behalf of Tipico Co. Ltd, a company established in Malta. The mayor of the town having ordered it to stop trading, this company brought an action before the Administrative Court of Cologne, claiming that the public monopoly on bets on sporting competitions in force in the Land of North Rhine-Westphalia, on which the decision it wished to have annulled was based, is contrary to the freedom to provide services guaranteed by Article 56 TFEU. The Court ruled out provisionally, maintaining the effects of national legislation concerning a public monopoly on bets on sporting competitions, which comprises restrictions that are incompatible with the freedom of establishment and the freedom to provide services, because those restrictions do not contribute to limiting betting activities in a consistent and systematic manner (more on this in Beukers, 2011).

Most recently, however, the Court has ruled on the incompatibility of the Hungarian system of rules restricting gambling on its territory with EU law. In 2017, the Court held in Unibet ${ }^{48}$ that the Hungarian legislation on the authorisation of online games of chance was not compatible with the principle of the freedom to provide services. It found that that legislation limited, first, in a discriminatory manner, and, second, by reason of its non-transparent nature, the opportunity for operators established in other Member States to organise such games in Hungary. Unibet International is a company established in Malta whose business consists in particular in the organisation of online games of chance and which, to that end, holds licences issued by several Member States. In 2014, the Hungarian authorities established that Unibet was providing, on Hungarian-language Internet sites, services relating to games of chance even though it did not hold the licence required in Hungary to carry on such an activity. Subsequently, those authorities ordered that access be temporarily blocked from Hungary to Unibet's Internet sites and imposed a fine on that company. Unibet thereupon brought an action before the Court in Budapest seeking

\footnotetext{
${ }^{47}$ Case C-409/06, Winner Wetten GmbH v Bürgermeisterin der Stadt Bergheim, ECLI:EU:C:2010:503.

${ }^{48}$ Case C-49/16, Unibet International Ltd $\mathrm{v}$ Nemzeti Adó- és Vámhivatal Központi Hivatala, ECLI:EU:C:2017:491.
} 
the annulment of those two decisions on the ground that the Hungarian legislation underlying them was contrary to the principle of the freedom to provide services. In that regard, Unibet took the view that, although, during the periods in dispute, operators established in other Member States could, theoretically, have been granted a licence in Hungary to organise online games of chance (as the provision of such services was not reserved to a State monopoly), it was in practice impossible for them to obtain such a licence.

The Court ruled that the Hungarian legislation concerned did not satisfy the requirement of transparency in so far as neither the conditions governing the exercise by the national authorities of their powers during the procedures for awarding concessions to »trustworthy « operators of game of chance nor the technical conditions which operators must satisfy when submitting their tenders had been defined with sufficient precision. In those circumstances, the Court concluded that the principle of the freedom to provide services also precluded that legislation. Finally, the Court stated that no penalties may be imposed on the basis of rules held to be contrary to the EU law.

Moreover, in February 2018 the Court held in Sporting Odds ${ }^{49}$ that the Hungarian legislation on the grant of concessions for operating traditional casinos and that relating to the organisation of online casino games are not compatible with EU law. The Court namely found that the Hungarian legislation prevents, in a discriminatory manner, operators of games of chance established in another Member State from having access to the Hungarian market for those games. The Court stated that the Hungarian legislation reserves the possibility to obtain a licence to organise online casino games exclusively to operators managing a casino under a concession on national territory, which constitutes a discriminatory restriction. In that connection, the Court considered that such a radical restriction of the principle of freedom to provide services cannot be justified by the objectives of public order and public health, which were the two premises upon which the Hungarian Government relied in support of the legislation. The Court reasoned that those objectives may be attained by less restrictive measures. The Court thus ruled that neither the Hungarian legislation on granting concession to operate traditional casinos nor that relating to the organisation of online casino games are compatible with the principle of freedom to provide services.

Accordingly, it may be concluded that despite much talk around the »revolutionary « rulings of the Court in a long series of cases referred to it by the national courts, the national borders as regards games of chance will subsist. There is namely still significant room for national rhetoricians with good argumentation skills, who can justify restrictive national measures and thus prevent floods of games of chance, domestic and foreign. These nationalistic, protectionist tactics are also motivated by the significant numbers of employees in the gaming industry - in Belgium over 10.000 persons worked in this sector; in Germany over 65.000 persons and in the United Kingdom over 100.000 (Study of games of chance in the European Union,

49 Case C-3/17, Sporting Odds Limited v Nemzeti Adó- és Vámhivatal Központi Irányítása, ECLI:EU:C:2018:130. 


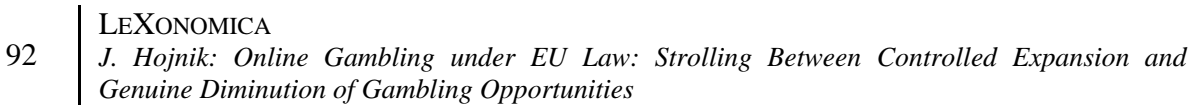

carried out by the Swiss Institute of Comparative Law at the request of the Commission on 14 June 2006).

\section{European Commission: gambling or leaving nothing to the chance?}

This casuistic approach by the Court is, however, evidently led to uncertainty for the Member States and gambling providers. From the point of view of the European Commission, this is hardly the right path to tread in an increasingly integrated EU.

\subsection{First way of »tackling the problem« - infringement procedures}

The Advocate General's opinion in HIT and HIT LARIX proposed a more restrictive approach that would have taken into account the risks for protectionism raised by a rule like Austria`s. Since the early 1990`s, the Commission has kept a firm eye on the gambling sector and has become very critical about protectionist national gambling laws, which often illegitimately restrict free movement of goods, services and freedom of establishment. In this regard the Commission was using different instruments to achieve at least a quasi-single European gambling market. Nevertheless, the Commission is being politically realistic in Member State`s reluctance to support an establishment of a true single market for games of chance. The former Head of the Services Unit at the Internal market DG Bergevin, is reported as stating, that »the Member States frankly don «t want us sticking our noses in at all and certainly don«t want an internal market for on-line gambling" (Gellatly, 2007). Additionally, in early 2007 the Internal Market Commissioner McCreevy told the European Parliament that on the question of European gambling harmonisation »It«s not my intention to bring forward a harmonised piece of legislation on gambling in the European Union« (Jones, 2007).

The vast majority of the Commission`s resources were being invested in considering possible infringement actions against a number of Member States for unlawful restrictions of the supply of certain gambling services. The Commission`s complaint was that the Member States in question appear to be invoking public interest grounds to restrict access to gambling services offered by non-nationals, while encouraging such state-run activities in order to obtain revenue.

In the last few years the Commission complained in relation to several Member State`s gambling legislation:

- against Denmark for Danish law restricting in particular the provision of sports betting services;

- against Greece, which explicitly forbade electronic games with electronic mechanisms and software from public and private places; the law had been introduced in an attempt to stamp out illegal gambling, with offenders facing fines of 5,000 to 75,000 euros and imprisonment of one to 12 months; 
- against Austria, France, Italy Germany, Finland, Sweden, Holland and Hungary for invoking the need to restrict its citizen`s access to gambling services while at the same time inciting and encouraging them to participate in state lotteries, games of chance or betting which benefits the state`s finances.

The Commission, however, generally appeared rather pessimistic about the use of court action to achieve market opening, with Bergevin remarking that: »I $d$ give it even odds on whether the courts will help the betting industry or close the market further. Whatever happens, you should never place all your trust on what judges think «. In relation to all the infringement procedures the Commission was emphasising, that any potential action "relates only to the compatibility of the national measures in question with existing EU law « (e.g. Press Release IP/06/1362) and that »(i)t does not touch upon the existence of monopolies as such, or on national lotteries. Nor does it have any implications for the liberalisation of the market for gambling services generally, or for the entitlement of Member States to seek to protect the general interest, so long as this is done in a manner consistent with EU law i.e. that any measures are necessary, proportionate and nondiscriminatory."

Nevertheless, in late 2017 the Commission decided to close infringement procedures and complaints in the gambling sector. ${ }^{50}$ The decision is in line with its political commitment to be more strategic in enforcing EU law. The Commission considered that complaints in the gambling sector can be handled more efficiently by national courts and also in the light of the numerous judgments of the Court on national gambling legislation. Complainants are therefore encouraged to make use of national remedies when facing problems with EU law in the gambling sector. The Commission also pointed out that the Member States are autonomous in the way they organise their gambling services, including the level of taxation, provided the fundamental freedoms of the Treaty are respected. The Commission further acknowledged the broader political legitimacy of the public interest objectives that Member States are pursuing when regulating gambling services. The Commission also noted Member States« efforts to modernise their online gambling legal frameworks, channel citizens « demand for gambling from unregulated offer to authorised and supervised websites, and ensure that operators pay taxes. With that in mind, the Commission concluded that it is not a priority for the Commission to use its infringement powers to promote an EU internal market in the area of online gambling services.

Perhaps it is not realistic to expect the European Commission to fully liberalise the EU gaming market. However, it is clear that Member States will have to stop invoking important reasons of public order to justify gaming restrictions, while the actual objective pursued is the protection of the national markets from foreign competition. Despite the before mentioned cautious approach of the Commission, some Member States nevertheless decided to liberalise the gambling sector even

\footnotetext{
${ }^{50}$ Press Release IP-17-5109.
} 
$94 \quad \begin{aligned} & \text { LEXONOMICA } \\ & \text { J. Hojnik: Online Gambling under EU Law: Strolling Between Controlled Expansion and } \\ & \text { Genuine Diminution of Gambling Opportunities }\end{aligned}$

before the Commission «s closure of all open infringement actions in the field. Among them is France, which announced its intent to partially open up its betting market and act as a role-model for the other Member States. French financial minister Woerth explained »Proceedings against France regarding our online betting market monopoly have been open since June 2007. In these circumstances, either we dig in our heels or we change our position. We have settled upon a controlled opening up of our online betting market«. The announcement has soon after been brought to effect (Ninivin, 2008).

\subsection{Second way of »tackling the problem« - regulatory activities}

Alternatively, a number of commentators (e.g. Caligiuri, 2012) and trade bodies have argued for greater harmonization in this area. The Commission has struggled to insert the country of origin principle in the EU legislation concerning gambling. According to this principle, a gaming operator should only comply with the law of its country of origin and could not be subjected to additional requirements for the cross-border provision and promotion of its services. Two acts were at front:

- Electronic Commerce Directive; and

- Directive on Services in the Internal Market.

The E-Commerce Directive (Directive 2000/31/EC of the European Parliament and of the Council of 8 June 2000 on certain legal aspects of information society services, in particular electronic commerce, in the Internal Market) ${ }^{51}$ provides the legal framework for electronic commerce in the Internal Market. The Directive removes obstacles to cross-border online services by providing the country of origin principle (or the Internal Market clause), which means that information society services are, in principle, subject to the law of the Member State in which the service provider is established and the Member State in which the information society service is received cannot restrict incoming services. Notwithstanding this, however, Article 1(5) of the E-Commerce Directive excludes gambling activities, which involve wagering a stake with monetary value in games of chance, including lotteries and betting transactions, from its scope of application. Therefore, the country of origin principle concerning the cross-border provision of information society services cannot be invoked as regards games of chance.

For this reason, the Commission soon after the Court's rulings in Gambelli and Lindman issued a press release, where it stressed that online gambling is a new area in which action may be required because of significant Internal Market problems. ${ }^{52}$ The Commission announced that it would examine the need for and scope of a possible new EU initiative. In the past years, however, no plans for amendments of the E-Commerce Directive as gambling is concerned have been announced and it can be doubted when (if ever) in the future the Directive will be of application on

\footnotetext{
${ }^{51}$ OJ L 178, 17. 7. 2000, pp. 1-16.

${ }^{52}$ IP/03/1580 of 21 November 2003.
} 
this sector. After the developments in relation to the Services directive the Commission`s inactivity comes as no surprise.

The original proposal of the Directive on services in the internal market (the Bolkestein`s proposal) foresaw removing barriers to cross-border provision of services on the basis of the country of origin principle. The proposal was harshly criticised for supporting regulatory competition between the Member States and has substantially been amended and finally adopted as the Directive 2006/123/EC of the European Parliament and of the Council of 12 December 2006 on services in the internal market. ${ }^{53}$

While the proposal was in the legislative procedure, the European Lotteries Association argued that games of chance had nothing in common with the aims of the proposed directive and that gambling is not suitable for being subjected to the internal market principles. The Association claimed that applying these principles for gambling would trigger a damaging liberalisation of the gambling sector and that sport's revenues would be jeopardised, ${ }^{54}$ The EU`s legislator supported this view and exempted gambling from the Directive`s application.

The adopted Directive 2006/123/EC therefore (despite removing the country of origin principle altogether) defines games of chance as a services sector, which is excluded from its application (Article 2(2)(h)). According to the Commission explanation: »The exclusion in Article 2(2)(h) covers any service which involves wagering a stake with pecuniary value in games of chance, including in particular, numeric games such as lotteries, scratch cards, gambling services offered in casinos or licensed premises, betting services, bingo services and gambling services operated by and for the benefit of charities or non-profit-making organisations. In contrast, games of skill, gaming machines that do not give prizes or that give prizes only in the form of free games and promotional games whose exclusive purpose is to encourage the sale of goods or services are not covered by the exclusion and thus benefit from the Services Directive. Furthermore, other services provided in casinos, for example the sale of food and drinks, are also not covered by the exclusion and have to be covered by implementing measures « (Handbook on the implementation of the Services Directive, p. 12). Nevertheless, national rules regulating games of chance need to be consistent with Article 56 TFEU and it will be left to the Court to determine the competence of Member States that seek to restrict or prevent the provision of gambling services across Member States.

Similarly, 》(g)ames of chance, involving a stake representing a sum of money, including lotteries, betting and other forms of gambling services, as well as on-line games and search engines « are excluded from the Directive 2010/13/EU of the European Parliament and of the Council of 10 March 2010 on the coordination of certain provisions laid down by law, regulation or administrative action in Member States concerning the provision of audiovisual media services (Audio-visual Media

\footnotetext{
${ }^{53}$ OJ L 376, 27. 12. 2006, pp. 36-68.

${ }^{54}$ Will amateur sport lose out in the EU services directive?, Euractiv, 11. 3. 2005.
} 
Services Directive), ${ }^{55}$ which amends and renames the Television without Frontiers Directive. The directive covers all audio-visual media services -traditional television (linear service) and video-on-demand (non-linear services) - and assures that service providers are subject only to the rules applicable in their own country (country of origin principle). Games of chance are excluded from the Directive, as it excludes all services whose principal purpose is not the provision of programmes, i.e. where any audio-visual content is merely incidental to the service and not its principal purpose..$^{56}$

How realistic it is for the two EU legislators to actually pass such a piece of legislation, however, may be ascertained by the critics of the European Parliament in relation to the Commission «s White Paper on Sport in the EU, ${ }^{57}$ where the Parliament voiced its concern at a possible deregulation of national gambling markets. It stressed that the revenues generated by state-owned or state-licensed lotteries are »the most important source of income « and »indispensable « for sports organisations in the EU and warned that no sustainable and politically feasible alternative to this funding in the event of a liberalisation has so far been either proposed or seriously discussed. ${ }^{58}$ Moreover, in 2010 the Competitiveness Council ${ }^{59}$ pointed out that the need to effectively regulate gambling services requires that Member States supervise the provision of gambling services in their territories through regulatory public authorities, established according to national legislation.

\subsection{Soft law approach to coordinating gambling regulation}

After gambling services being excluded from the Services Directive and every other legislation connected to gambling and further after the former Internal Market Commissioner announced giving up on any harmonisation plans, the Commission focused instead on a soft law approach towards coordinating national regulations on gambling.

The first step in this direction could be found in an extensive study on gambling in the EU, which was requested from the Swiss Institute of Comparative Law by the Commission. The study on gambling provides an analysis of the national regimes governing gambling in the EU and confirms that in all Member States the sector is subject to rules and regulations aimed at safeguarding public interest objectives. While pursuing broadly similar aims, the national laws and regulations vary considerably and often lead to barriers to the freedom to provide services and the freedom of establishment that are incompatible with Community law.

In line with the Council's conclusions of 2010, the Commission adopted a Green Paper on online gambling in the Internal Market in 2011.60 The Commission`s

\footnotetext{
${ }^{55}$ OJ L 332, 18. 12. 2007, pp. 27-45.

${ }^{56}$ Audio-visual Media Services Directive, preambule, rec. 18.

${ }^{57}$ COM(2007) 391 final.

${ }^{58}$ European Parliament warns of gambling liberalisation, European Lotteries Press Release, 8 May 2008.

${ }^{59}$ 3057th Competitiveness Council conclusions, 2010.

${ }^{60} \mathrm{COM}(2011) 128$ final.
} 
conclusion from the public consultation performed was that it did not appear appropriate at this stage to propose sector specific EU legislation. However, there was an almost unanimous call for policy action at the EU level and the responses allow for a clear identification of the key priority areas where action is required.

Consequently, the Commission by way of a Communication of $2012,{ }^{61}$ together with the accompanying Commission Staff Working Document, identified the key challenges posed by the co-existence of national regulatory frameworks within the internal market. In particular, it was pointed out that in view of the developments regarding the offer and promotion of online gambling in the EU, greater clarity was needed. The 2012 Communication proposes a combination of initiatives and relevant measures covering a range of issues, seeking to enhance legal clarity and establish policies based on available evidence, highlighting five priority areas to address, i.e. compliance of national regulatory frameworks with EU law; enhancing administrative cooperation and efficient enforcement; protecting consumers and citizens, minors and vulnerable groups; preventing fraud and money laundering; and, safeguarding the integrity of sports and preventing match-fixing. The proposed actions focus on online gambling services and issues linked to the free movement of services and the freedom of establishment in light of the growth of online gambling in the EU and the well-developed cross-border supply of such services.

In line with this commitment, in 2014 the Commission adopted the Recommendation on principles for the protection of consumers and players of online gambling services and the prevention of minors from gambling. ${ }^{62}$ The recommendation encourages EU Member States to ensure a high level of protection for consumers and minors through the adoption of principles for online gambling services and for responsible advertising and sponsorship (more on this in Griffiths, 2005).

Furthermore, in November 2015, gambling regulatory authorities of EEA Member States signed a cooperation arrangement to enhance administrative cooperation. The arrangement covers a number of different areas, such as the organisation of gambling, including tender procedures; verification of information provided by other authorities and exchange of technical expertise; the supervision of compliance with national laws, including the protection of consumers; prevention of money laundering and fraud; $d$ betting related to match-fixing; and, practical cooperation to assist authorities in their day-to-day supervisory function and sharing of good practices. The cooperation arrangement is accompanied by files (»gateways «) on the participating countries. These gateways provide information on the role and remit of national authorities, areas they would like to share information on, competences of other national authorities with regards to gambling, as well as any limitations in laws e.g. regarding data protection.

Moreover, the European Commission adopted a decision in April 2018 requesting the European Committee for Standardisation to draft a European standard on reporting in support of supervision of online gambling services by the gambling

\footnotetext{
${ }^{61}$ COM (2012) 596 final.

${ }^{62}$ 2014/478/EU, OJ L 214, 19. 7. 2014, pp. 38-46.
} 
regulatory authorities in EU Member States. Standardisation in this field aims to develop a voluntary tool to facilitate the flow of information between regulatory authorities in EU Member States and the operators and suppliers. It would define the core elements for reporting purposes. However, the Commission noted that the standard would be without prejudice to the scope of competence of EU country authorities in the regulation of online gambling and would not impose any obligation on them to introduce reporting requirements or to authorise or deny authorisation to any operators or suppliers.

\section{Conclusion}

As EGBA has rightly emphasized in its 2018 Manifesto titled »A EU Framework For Online Gambling 2.0«, Europe«s current online gambling regulation is highly fragmented causing many problems for consumers, gambling authorities and online gambling companies. Since the launch of the EU Digital Single Market the European Commission has been committed to deepening integration of the digital economy and ensuring consumers are better protected online. But that has not been the case for the millions of Europeans who gamble online. The most recent European Commission Communication on online gambling in Europe is from 2012 and, given major technological and regulatory developments since, is out of date and should be reviewed. We may or may not agree as to whether liberalisation of gambling would be detrimental to EU citizens. It is nevertheless true that a uniform approach to all types of gambling is not the right approach. Games of chance are namely a very complex sector of services. Both the methods of playing as well as their social consequences are complex. Certain games of chance are therefore more suitable for competition rules than are others.

The whole activity of lotteries, for example, may fail if there is no limitation as to the number of lotto services offered on the market of a Member State. The winning pot is namely rising on the basis of player's payments and a significant sector of the public purchase tickets only when the potential winnings are extremely high. In circumstances where there are a large number of lotto providers the pot would raise slowly as only smaller number of players would be interested in playing and thus many lotto providers would not exist for long. Indeed, this could be one way of protecting people from gambling. As the Portuguese government in Gambelli emphasised, there is, however, another danger in this regard - free cross-border gambling would enable establishment of large European lotteries with enormous winnings, which would attract players from all the EU and where the income would flow from the small to large EU Member States. Players would participate in lotteries that provide the highest winning and thus they would contribute to the social, cultural and sport budget of the large Member States. Under this scenario, the small States would need to make up for the loss of income by imposing higher taxes. On the other hand, in times of cross-border television and Internet, when EU citizens follow all major national football (and other sport's) leagues in Europe, it is probably unsound to limit their access to sport bets to national sport events only. 
Even though economic goals are not an acceptable justification for restrictive national gambling legislation as free movement of services is concerned, the financial importance of gambling services will no doubt denote future efforts to liberalise the sector. In this respect, one can expect conflicts between the Member States in various ways, not just between liberal and conservative states in terms of gambling regulation, but also between small and large Member States. States with large internal markets, and thus a prevalence of domestic gaming customers, typically try to limit the offering of games by imposing high taxes. Smaller States and economies with proportionally small internal markets, which rely largely on customers from other economies, are prone to offer low tax burdens and thus encourage gaming operators to create a more comprehensive non-gaming tourist amenities in order to export gambling and non-gambling services as much as possible and maximise the economic benefits with minimal negative social impacts. In this respect, the proportionality question will no doubt continue to arise in future gambling cases at the Court, particularly as Internet gambling and cross-border providers continue their fight to take maximum advantage of the free market provisions of EU law.

\section{References}

3057th Competitiveness Council conclusions on the framework for gambling and betting in the EU member states, 10 December 2010.

Abbott, M. W., Volberg, R. A., Bellringer, M., and Reith, G. (2004) A review of research aspects of problem gambling (London: Responsibility in Gambling Trust).

Azoulai, L. (2011) The Retained Power`s Formula in the Case Law of the European Court of Justice: EU Law as Total Law, European Journal of Legal Studies, 4, pp. 192-219.

Beukers, T. (2011) Case C-409/06, Winner Wetten GmbH v. Bürgermeisterin der Stadt Bergheim, Judgment of the Court (Grand Chamber) of 8 September 2010, Common Market Law Review, 48(6), pp. 1985-2004.

Bogaert, S., Cuyvers, A. (2011), Money for Nothing: The Case Law of the EU Court of Justice on the Regulating of Gambling, Common Market Law Review, 48(4), pp. 1175-1213.

Caligiuri, P. (2012) Uncle Sven Knows Best: The EJC, Swedish Gambling Restrictions, and Outmoded Proportionality Analysis, Boston College International and Comparative Law Review, 35 (2), pp. 575-588.

Collins, D. and Lapsley, H. (2003) The Social Costs and Benefits of Gambling: An Introduction to the Economic Issues, Journal of Gambling Studies, 19(2), pp. 123148.

Del Ninno, A. (2007) The Placanica Decision: The EU Court of Justice Again Censures Italy`s Restrictions on the Gambling Market, Gaming Law Review, 11(3), pp. 241246.

Delfabbro, P. and King, D. (2012) Gambling in Australia: experiences, problems, research and policy, Addiction, 107(9), pp. 1556-1561.

EGBA Publishes EU Online Gambling Key Figures For 2017, Press Release, 27 November 2018.

EGBA, Manifesto: A EU Framework For Online Gambling 2.0, 7 December 2018.

Euchner, E-M., Heichel, S., Nebel, K., and Raschzok, A. (2013) From »morality« policy to »normal« policy: framing of drug consumption and gambling in Germany and the 
$100 \begin{aligned} & \text { LEXONOMICA } \\ & \text { J. Hojnik: Online Gambling under EU Law: Strolling Between Controlled Expansion and } \\ & \text { Genuine Diminution of Gambling Opportunities }\end{aligned}$

Netherlands and their regulatory consequences, Journal of European Public Policy, 20(3), pp. 372-389.

European Lotteries (2004), Consultation on a New Legal Framework for Payments in the Internal Market, Position paper,

http://europa.eu.int/comm/internal_market/payments/docs/framework/2004contributions/european-lotteries_en.pdf

European Parliament warns of gambling liberalisation, European Lotteries Press Release, 8 May 2008,

https://www.european-lotteries.org/data/info_1439/080508_EL_press_vote_WP_Sport.pdf

Frank, M. L., Lester, D., and Wexler, A. (1991) Suicidal Behavior among Members of Gamblers Anonymous, Journal of Gambling Studies, 7(3), pp. 249-254.

Gellatly, A. (2007) Prospects for European Change Drifting According To EU Representative, www.gamblingcompliance.com/node/7115.

Griffiths, M. D. (1996) Pathological gambling: A review of the literature, Journal of Psychiatric and Mental Health Nursing, 3, pp. 347-353.

Griffiths, M. D. (2004) Betting your life on it: Problem gambling has clear health related consequences, British Medical Journal, 329, pp. 1055-1056.

Griffiths, M. D. (2005) Does advertising of gambling increase gambling addiction? International Journal of Mental Health and Addiction, 3(2), pp. 15-25.

Griffiths, M., Hayer, T. and Meyer, G. eds. (2009) Problem Gambling in Europe (New York: Springer).

Grinols, E. L. (2009) Gambling in America: Costs and Benefits (Cambridge: Cambridge University Press).

Grinols, E., Omorov, J. D. (1996) Who Losses When Casinos Win?, Illinois Business Review, 53(1), pp. 7-11.

Hatzopoulos, V. (1995) Case Note: Her Majesty`s Customs and Excise v. Gerhart und Jörg Schindler, C-275/92, Common Market Law Review, 32(3), pp. 841-855.

Jones, H. (2007) UPDATE 2-EU may challenge U.S. online gambling law-McCreevy, Reuters, $\quad 30 \quad$ January 2007, http://www.reuters.com/article/governmentFilingsNews/idUSL3091817720070130.

Keuleers, E. (2005) Gambelli: The Need for a European Framework for Remote Gaming, Gaming Law Review, 9(2), pp. 134-135.

Kingma, S.F. (2008) The liberalization and (re)regulation of Dutch gambling markets: National consequences of the changing European context, Regulation and Governance, 2(4), pp. 445-458.

Laffey, D., Della Sala, V. and Laffey, K. (2016) Patriot games: the regulation of online gambling in the European Union, Journal of European Public Policy, 23(10), pp. $1425-1441$.

Lesieur, H. R. (1998), Costs and Treatment of Pathological Gambling, Annals of the American Academy of Political and Social Science, 556(1), pp. 153-171.

Littler, A. (2001) Member States versus the European Union: The Regulation of Gambling (Leiden: Martinus Nijhoff Publishers).

Littler, A. (2007) The regulation of gambling at European level: The balance to be found, ERA Forum, 8, pp. 357-371.

Marionneau, V. (2015) Justifications of national gambling policies in France and Finland, Nordic Studies on Alcohol and Drugs, 32(3), pp. 295-310.

McMillen, J. (2007) Cross-cultural comparisons, in Smith, G., Hodgins, D.C. and Williams, R.J. (Eds.), Research and measurement issues in gambling studies, pp. 465-489) (New York: Elsevier).

Meyer, G., and Stadler, M. (1999) Criminal behaviour associated with pathological gambling. Journal of Gambling Studies, 5, pp. 29-43. 
Ninivin, A. (2008) L`annonce de l’ouverture du marché des jeux et paris sportifs en ligne: un évènement attendu, La Revue, 29.07.2008,

http://larevue.hammonds.fr/L-annonce-de-l-ouverture-du-marche-des-jeux-et-paris-sportifsen-ligne-un-evenement-attendu_a691.html.

Örnberg, J. C., Tammi, T. (2011) Gambling problems as a political framing - Safeguarding the monopolies in Finland and Sweden, Journal of Gambling Issues, 2011(26), pp. $110-125$.

Spindler, G., Hambach, W., \& Berberich, B. (2011) The Carmen Media Case - The Expected Catalyst from Brussels for a New Approach to German Gambling Law? European Journal of Risk Regulation, 2(1), pp. 135-142.

Straetmans, G. (2000) Case C-124/97, Läärä and Case C-67/98, Zenatti, Common Market Law Review, 37(4), pp. 991-1005.

Straetmans, G. (2004) Casenote on Anomar, Gambelli and Lindman, Common Market Law Review, 41(5), pp. 1409-1428.

Swiss Institute of Comparative Law (2006) Study of gambling services in the internal market of the European Union, Final report, European Commission,

http://ec.europa.eu/internal_market/services/gambling_en.htm

Thompson, W., Gazel, R. and Rickman, D. (2000) Social Costs Of Gambling: A Comparative Study Of Nutmeg And Cheese State Gamblers, UNLV Gaming Research \& Review Journal, 5(1), pp. 1-16.

Walker, D. (2001) Is Professional Gambling a Directly Unproductive Profit-seeking (dup) Activity?, International Gambling Studies, 1(1), pp. 177-183.

Walker, D. M. and Barnett, A.H. (1999) The Social Costs of Gambling: An Economic Perspective, Journal of Gambling Studies, 15(3), pp. 181-212.

Wynne, H. J. and Shaffer, H. J. (2003) The Socioeconomic Impact of Gambling: The Whistler Symposium, Journal of Gambling Studies, 19(2), pp. 111-121. 
102 | LeXonomica 